\title{
Spatial model of land subsidence mitigation at lowland areas
}

\author{
Andriani Andriani ${ }^{*}$, Hafizah Novasari ${ }^{1}$, Masril Syukur ${ }^{1}$, and M. Shubhi Nurul Hadie $^{1}$ \\ ${ }^{1}$ Civil Engineering Departement, Andalas University, Padang, West Sumatera, Indonesia 25163
}

\begin{abstract}
South Sumatera is one of the provinces with a large number of lowlands in Indonesia consisting of tidal land and lowland swamps, one of which is located in Tanjung Api-Api. The conversion of lowlands into built-up areas will cause physical, socio-economic, environmental, and public health impacts. One of the impacts arising from the development of settlements and infrastructure in lowland areas is land subsidence and flooding. The purpose of this research is to create a model for mitigating land subsidence in lowland areas spatially. The spatial model is carried out by weighting with Analytical Hierarchy Processes (AHP) and then mapping mitigation efforts that will be carried out based on the potential for land subsidence. The results show that if the lowland area is developed into an industrial and residential area, it will have an impact on land subsidence with a moderate to high potential level. Based on the zoning of the potential for land subsidence, the best pre-disaster mitigation efforts to do are choosing the type of construction according to the type of soil, conserving groundwater, maintaining infiltration areas and green open spaces, and regional spatial planning.
\end{abstract}

\section{Introduction}

The plan of development of a special economic zone in Tanjung Api-Api will change the environmental ecosystem, a large-scale landfill at the research site will affect environmental conditions, including the surrounding soil conditions. This will affect the lowland ecosystem in the region because lowlands have a very large environmental role. The development of residential and industrial areas on a large scale in the Tanjung ApiApi area will trigger land subsidence. Land subsidence is a problem faced by many big cities in the world and Indonesia. The impact of land subsidence will have direct and indirect impacts on human life; both physical, socioeconomic, health, and environmental impacts [1]. To reduce the impact arising from land subsidence, it is necessary to carry out mitigation. Mitigation is an action to reduce the effects of natural disasters so that the resulting disasters do not cause a major impact. Disaster Mitigation Actions include the collection and analysis of disaster data to reduce the level of vulnerability and danger of a disaster, predict disaster events, preparedness, emergencies, and socialization of disasters through print media and lectures [2].

Natural disasters are a series of events caused by nature. Natural disasters can be caused by natural factors, such as geological factors, geomorphology, high rainfall, and others [3]. This will trigger natural disasters, such as floods in the rainy season and drought in the dry season, landslides and ground movements, land subsidence and liquefaction, earthquakes and tsunamis, and others. Disaster mitigation efforts are a process of anticipating disasters that will arise through urban planning and design. Disaster mitigation efforts can be displayed with a conceptual model. The conceptual model is a diagram of a set of relationships between certain factors that are believed to have an impact on or lead to a target condition [4]. Conceptual model of disaster mitigation that aims to avoid disasters, in two ways, namely: structural mitigation, namely efforts in the form of strengthening buildings or infrastructure and avoiding potential disaster areas and non-structural mitigation by not changing the natural environment that can protect against disasters, in addition to potential wisdom local communities can contribute to disaster mitigation [5].

Mitigation efforts to overcome land subsidence can be done technically and non-technically. The technical way to overcome land subsidence is to improve soil characteristics, make infiltration wells/ biopore, and others. To reduce subsidence and flooding problems, it is necessary to conserve underground water, by limiting the use of drilled wells and making injection wells [6]. Mitigation of land subsidence can be done by regulating the use of groundwater (limiting the construction of wells and excessive use of groundwater) [7]. Regulating the hydrological condition of peat soil by maintaining the water table and restoring the groundwater level is one way that can be used to prevent peat soil subsidence, peat soil decomposition, peat fires, and $\mathrm{CO} 2$ emissions [8]. To minimize the impact due to the development of

* Corresponding author: andriani@eng.unand.ac.id 
settlements in lowlands, it can be done by making infiltration wells, biopore, maintaining vegetation, and renaturalizing rivers [9].

Disaster mitigation actions can be carried out before and after a disaster occurs, to minimize casualties, preventive measures must be prepared as early as possible, preventive efforts are carried out to avoid large impacts on areas indicated by disasters. Natural disasters can be local but can also be widespread, causing macro impacts. One way that can be done to mitigate disasters is by spatial planning, to reduce physical and economic losses due to disasters [10]. Mitigation activities include risk assessment and determination of potential disaster impacts [11].

Geospatial information is one of the methods used to determine areas that are prone to land subsidence, then using spatial modeling can be done to mitigate land subsidence in lowland areas.

\section{Research Methodology}

\subsection{Research Location}

The Tanjung Api-Api area is part of the Banyuasin district which is located in the Banyuasin II sub-district and is located at coordinates $104^{\circ} 45^{\prime}$ to $104^{\circ} 55^{\prime}$ E Longitude and $2^{\circ} 17^{\prime}$ to $2^{\circ} 24^{\prime} \mathrm{S}$ Latitude and is along the East coast of Sumatra Island. The existence of the Tanjung Api-Api port and the planned development of a Special Economic Zone has caused the Banyuasin district to have a very important role as a center for downstream industries. The Tanjung Api-Api area has been developed since 1969 through the transmigration program as an agricultural and residential area [12], currently, in the Tanjung Api-Api area, the Tanjung Api-Api port has been built. The existence of plans for the construction of the international port of Tanjung Carat and the Special Economic Zone in Tanjung Api-Api requires special handling because it is located on lowland and soft soil so that the potential for land degradation is likely to occur. Fig. 1 shows the planned location for the construction of the Special Economic Zone.

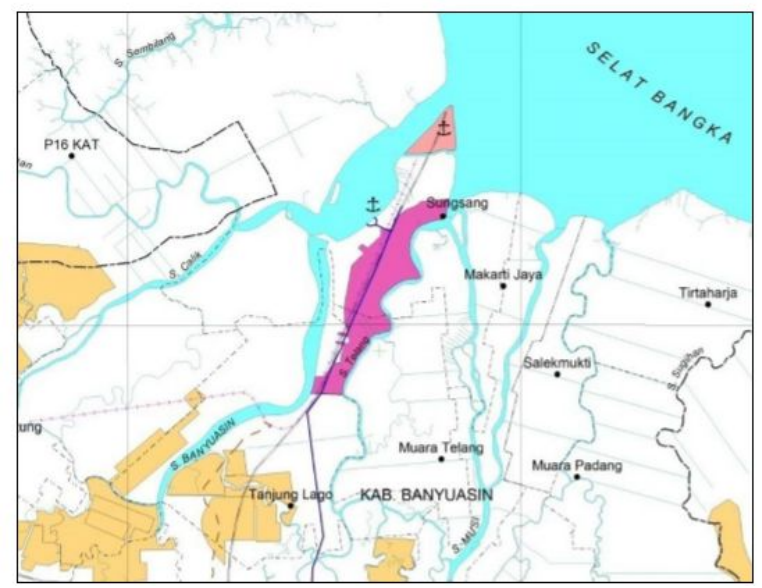

Fig. 1. The Plan of Special Economic Zone at Tanjung ApiApi) [13]
Fig. 2 shows the distribution of soft soil in Indonesia. From the map, it can be seen that the area along the east coast of Sumatra Island consists of soft soil, namely peat soil and soft clay [14] so that it has the potential to experience land subsidence when reclaimed.

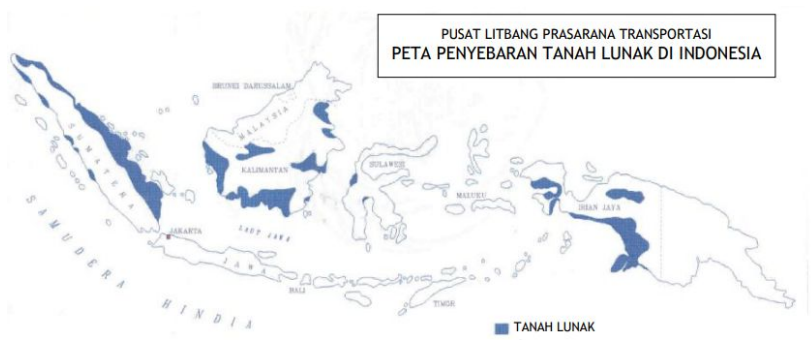

Fig. 2. Map of Soft Soil Distribution in Indonesia

\subsection{Data Analysis}

To reduce the impact of land subsidence, mitigation efforts are carried out. In this study, mitigation efforts were carried out before the disaster occurred. There are many criteria used to determine disaster mitigation. To determine the magnitude of the weight of each criterion factor used the Analytic Hierarchy Process (AHP) method. AHP is a decision-making approach designed to help find solutions to complex multi-criteria problems [15], to determine decisions using criteria and alternative decisions in determining the final goal of a decision or decision suggestion. The AHP process is based on the assessment criteria for decisions from alternatives.

Assessment of mitigation efforts is carried out by processing questionnaire data obtained from experts using AHP. The experts used in this study amounted to 20 people who came from academics and practitioners who are experts in the fields of environment, disaster, and geotechnics. Furthermore, the validation of AHP results is carried out by conducting field observations and studies from previous journals. Mapping of mitigation efforts is carried out based on the results of the weighting obtained from the expert. The mapping was carried out using QGIS 3.12.2, the results of weighting and interviews from experts were displayed in the form of thematic geospatial information.

Fig. 3 shows the hierarchical structure of land subsidence mitigation. Mitigation is carried out technically and non-technically. This step aims to break down a complex problem arranged into a hierarchical form. A hierarchical structure itself consists of elements that are grouped into levels consisting of the goals or goals of decision making, assessment criteria, and choices.

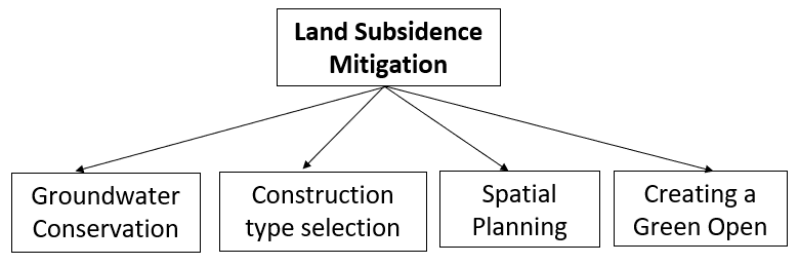

Fig. 3. The Hierarchical Arrangement of Land Subsidence Mitigation in Lowlands 


\section{Results and Discussion}

The results of previous studies indicate that the change in the Tanjung Api-Api area into a built area (residential and industrial areas) will trigger land subsidence. This occurs due to the embankment of the soil of more than $2 \mathrm{~m}$ and excessive groundwater extraction (deep wells). Currently, land use in the Tanjung Api-Api area is still dominated by forests, shrubs, agricultural land, and plantations, so the potential for land subsidence is still low. To anticipate high land subsidence due to area development, mitigation efforts need to be carried out to avoid and reduce the impacts that will occur due to land subsidence.

Mapping is one form of mitigation that can be done to reduce the impact that occurs. Based on the literature review, several things can be done to reduce the impact of land subsidence, namely selecting the appropriate type of construction to be applied in built-up areas and conserving groundwater. Groundwater conservation can be in the form of making infiltration wells, retention ponds, and biopore which function to fill groundwater (recharge) so that the pore does not empty.

Fig. 4 shows a conceptual model of land subsidence that can be carried out. The mitigation model consists of mitigation before land subsidence, during land subsidence, and after land subsidence. The conceptual model is an important set for mitigating soil subsidence in the lowland.

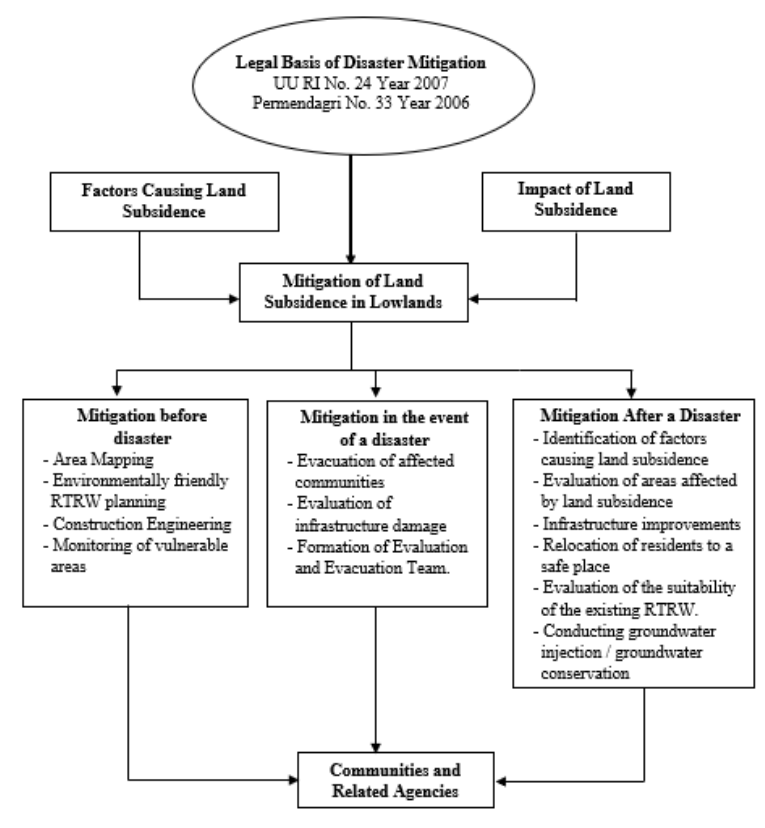

Fig. 4. Conceptual Model of Land Subsidence Mitigation Efforts.

The results of the questionnaire from the experts obtained weights for each criterion for mitigation of land subsidence.

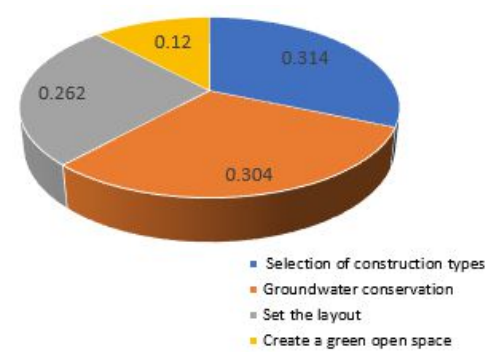

Fig. 5. Assessment of Land Subsidence Mitigation using by AHP

The selection of construction types weights 0.314 ; groundwater conservation with a weight of 0.304 ; set the layout with a weight of 0.262 ; and create a green open space with a weight of 0.12 .

The selection of the right type of construction is very necessary to overcome the impact of damage to infrastructure, the selection of construction type is influenced by the type of soil, the depth of the soft soil, and the load. The depth of soft soil will also affect the bearing capacity of the soil, the deeper the soft soil is the type of foundation that can continue the load of the building is needed, for example, pile foundations / drilled piles are used, while for roads it is better to use geosynthetic or other types of soil improvement and rigid pavement. Large loading will cause the potential for land subsidence so that special construction is needed that can carry the working load. The choice of embankment material is also needed to accelerate the process of land subsidence so that the soil is quickly stable and does not form pores due to less dense soil.

Groundwater conservation is carried out to overcome the land subsidence that occurs. The purpose of groundwater conservation is to maintain the balance of groundwater so that there is no emptying of pores that can cause soil subsidence and instability in buildings. Groundwater conservation can be in the form of making infiltration wells, biopore, and groundwater injection and 
can also be in the form of government policies on groundwater extraction.

The regulation of land use and its designation in lowland is very important to maintain the balance of carrying and environmental capacity so that the development of lowland does not cause environmental degradation. The selection of the most appropriate mitigation efforts depends on the factors causing land subsidence and the most dominant impact due to land subsidence. Factors causing land subsidence will affect the mitigation methods that can be applied at the research site. Based on the results of the study, it was found that the main factors causing soil subsidence were soil type, the thickness of soft soil, land use, embankment height, and groundwater use. The most suitable mitigation effort is to choose the type of construction that is suitable to be applied in the research area to prevent or reduce the impact of infrastructure damage in the research area, while water conservation efforts need to be carried out to anticipate floods and droughts that often occur in the Tanjung Api-Api area so that the presence of groundwater conservation can prevent the formation of pores in the soil due to excessive groundwater extraction $[16,17,18,19$, 20].

Fig. 6 shows the mitigation efforts for various land use based on the level of potential land subsidence at the stage before land subsidence occurs. The existence of a mapping of potential land subsidence in the research area will help to determine the direction of physical and nonphysical mitigation in the disaster-affected area. The results of the mapping carried out due to the conversion of lowlands in Tanjung Api-Api into a built-up area, industrial areas (Special Economic Zones), and settlements have a high potential for land subsidence [21]. The high potential for land subsidence in this area is due to the embankment height of more than 2 meters and the extraction of deep groundwater (bore wells). With the thematic geospatial information, the vulnerability of the area to potential land subsidence can be evaluated and the most appropriate policy direction for mitigation efforts can be determined to be applied to the research location.

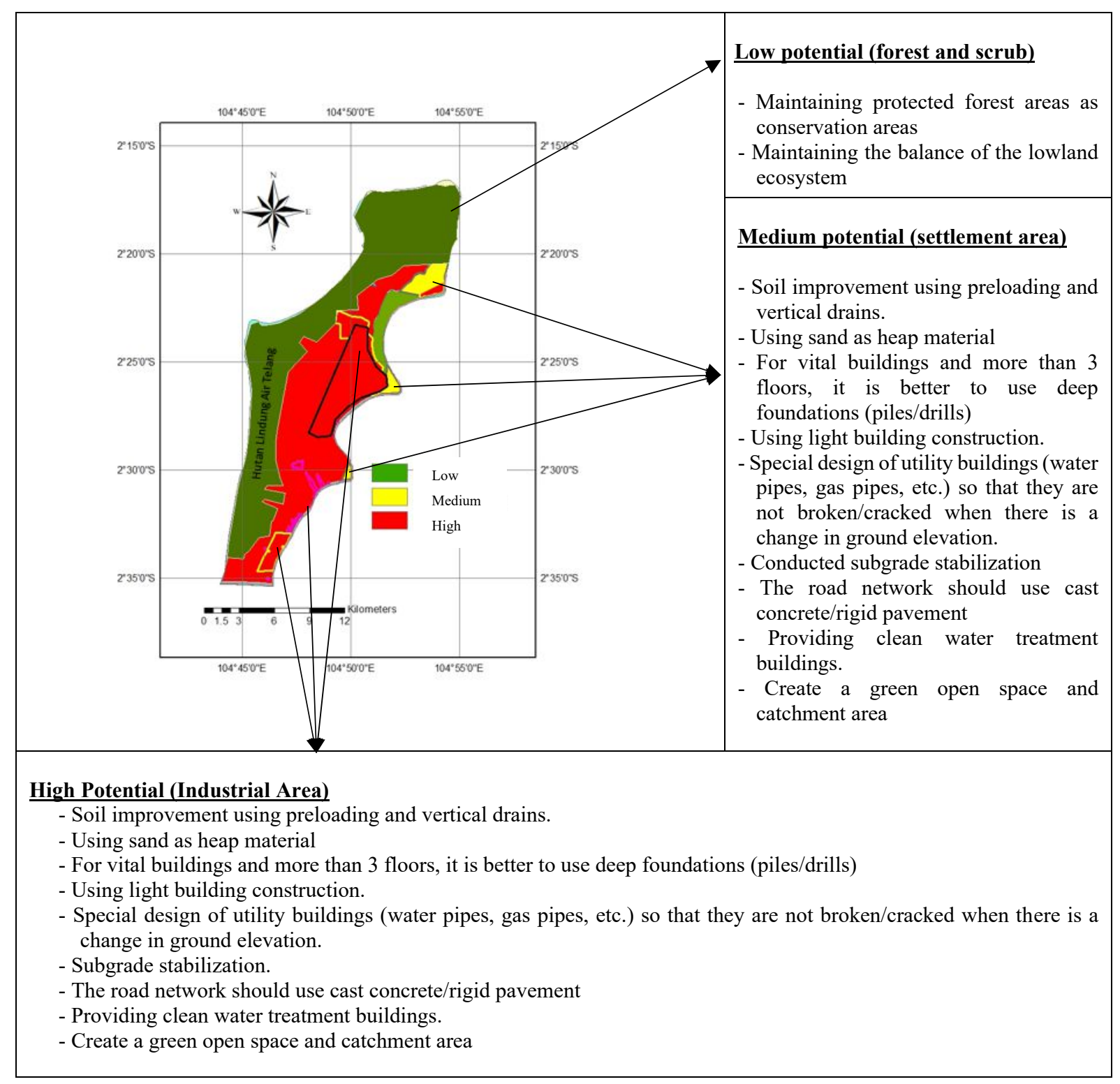

Fig. 6. Mitigation Spatial Model in the Stage Before Land Subsidence Occurs 


\section{Conclusions}

Based on the results of the study, it can be concluded as follows:

a. Conceptually, disaster mitigation can be done before, during, and after a disaster occurs. Mapping of areas that have the potential for land subsidence is one form of mitigation before a disaster occurs. Regional mapping is divided into areas with low, medium, and high potential. To select the most suitable mitigation efforts, AHP analysis is carried out and then applied spatially to locations based on the level of potential disaster, the existence of a map of potential land subsidence is expected to reduce the impact of disasters.

b. AHP results show that mitigation of land subsidence can be done by selecting the type of construction (weight 0.314), conserving groundwater (weight 0.304 ), adjusting the spatial arrangement (0.262), and creating green open space $(0.12)$. To obtain the most optimal mitigation model used depends on the regional development plan and land use.

This research was funded by a grant from Civil Engineering Department, Faculty of Engineering, Andalas University with Contract number: 119/UN16.09.D/PL/2021 for Fiscal Year 2021.

\section{References}

1. A. Andriani, E. Ibrahim, D.D.A. Putranto, A.K. Affandy, Evaluation of Land Subsidence Impact at Lowland Areas Using Analytical Hierarchy Process (AHP) Method, in Proceedings E3S Web Conf of the $1^{\text {st }}$ The $1^{\text {st }}$ Sriwijaya International Conference on Environmental Issues 2018 ( $1^{\text {st }}$ SRICOENV 2018), 2-11-2018, Palembang, Indonesia

2. I.A. Sadisun, Disaster Management: Living Strategies in Potentially Disaster Areas, (2014)

3. Anonymous, Law no. 24 of 2007 concerning Disaster Management R. Wikantiyoso, P. Tutuko., Group Konservasi Arsitektur \& Kota (2009)

4. R. Wikantiyoso, Local Wisdom, 2, 1 (2010)

5. D. Murdohardono, Buletin Geologi Tata Lingkungan (Bulletin of Environmental Geology), 12, 1 (2000)
6. M. Dehghani, A. Hooper, R. Hanssen, M.J.Z. Valadan, S.Saatchi, I. Entezam, Hybrid conventional and Persistent Scatterers SAR Interferometry for Land Subsidence Monitoring in southwest Tehran, Iran. Fringe Workshop, Italy (2009)

7. J. Jaenicke, H. Wosten, A. Budiman, Mitigation Adaptation Strategy Global Change, 15 (2010).

8. M.Rijal, P. Aldy, Jurnal Arsitektur UBL, 1, 3 (2012)

9. D.P.E. Putra, S. Agung., K. Keokhampui, H. Fukuoka, Land Subsidence Risk Asseessment in Karst Region, Case Study : Rongkop, Gunung Kidul, Yogyakarta-Indonesia. In: Mitteilungen zur Ingenieurgeologie und Hydrogeologie-Festschrift $z u$. RWTH Aachen University, German (2011)

10. C. Tarhan, C. Aydin, V. Tecim, Urban Planning and Architecture Design for Sustainable Development, UPADSD (2015)

11. Ngudiantoro, Jurnal Penelitian Sains, 13, 3(A) (2010)

12. BAPPEDA SUMSEL, Rencana Tata Ruang Wilayah Provinsi Sumatera Selatan (2012)

13. Anonim, Panduan Geoteknik 2, Puslitbang Prasarana Transportasi (1997)

14. T.L. Saaty, Int.J. Services Sciences, 1, 1 (2008)

15. L.P. Sien, C.C. Shieng, C.F. Sheng, H.T.Yuan, The Effect of Land Subsidence on the Embankment of the New Second Freeway in Taiwan. Proceedings of the Fifth International Symposium on Land Subsidence, The Hague, October 1995 (1995)

16. J.C. Chai, S.L. Shen, H.H. Zhu, X.L. Zhang, Lowland Tech. Int., 7,1 (2005)

17. D.L. Galloway, S. Michelle, Buletin DE LA Sociedad Geologica MEXICANA, 65 ,1 (2013)

18. F. Raspini, C. Loupasakis, D. Rozos, S. Moretti, Natural Hazards and Earth System Sciences, 13 (2013)

19. W. Yanlin, B. Xiangjun, F. Sheng, et al., Procedia Engineering, 15 (2011)

20. A. Andriani., E. Ibrahim., D.D.A. Putranto, A.K. Affandy, and H.G. Putra, Spatial analysis of land subsidence potential due to lowland conversion (case study at Tanjung Api-Api), in Proceedings IOP Conference Series: Material Science and Engineering, 933,012054, The $2^{\text {nd }}$ AISCE, 18-19 September 2019, Banda Aceh, Aceh Province, Indonesia (2019) 